referred to that more injustice is done to the profession than good to the cause advanced; and pructitioners of medicine have a right to feel offended at the aspersions thns publicly cast upon them by one of their number.

$$
\text { I am, Sir, your obedient servant, }
$$

Sor. $15 \% 0$. A Genefar Practitiojer.

\section{THE SPHYGMOGRAPH ANTICIPATED BY GALILEO.}

To the Editor of THE LANCrT.

Sra,-In the interesting "Life of Galileo," lately pubished by Mracmillan and Co, occurs the following paragraph respecting the sphygmograph :-

"The connexion of the great bronze lamp in the nare of the cathedral at Pisa with Galileo's earliest mechanical discovery is well known. Viviani says that, having observed the unerring regularity of the oscillations of this lamp and of other swinging bodies, the idea occurted to him that an instrument might be constructed on this principle which should mark with accuracy the rate and variation of the pulse. Such an instrument he constructed, after a long series of careful experiments. This invention, though imperfect, was hailed with wonder and delight by the physicians of the day, and was soon taiken into general nse, nnder the name of the Pulsilogia."

I am, Sir, your obedient servant,

Norwich, November 21st, 1870 Charles Williays, F.R.C.S.

\section{Gbituario.}

\section{WILLTAM J. TUBBS, M.R.C.S., I.R.C.P. EDTN.} (OF UPWELL.)

Thrs well-known practitioner in the Eastern counties died in London on the 11th inst., aged seventy. He was educated at Guy's Hospital, and became a Licentiate of the Apothecaries' Society in 1833. After twenty-five years' active practice, he had the zeal and energy to work up for and pass two examinations, and became M.R.C.S. Eng. in 18ว9, and L.R.C.P. Edin. in 1860. Mr. Iubbs was a great lover of, and worker in, his profession, and in scientific pursuits. About twenty years ago he devoted a great deal of time to laboratory rork, and became a good analytical chemist, of which he gave more than one proof in medicolegal investigations. He also deroted at one time a good deal of attention to mesmerism, and performed more than one operation under its influence. Latterly $M r$. Tubbs became a skilful photographer, and, in fact, was always ready to take up any new scientific discovery-e.g., the electrolytic treatment of tumours, \&c. During thirty years $\mathrm{Mr}$. Tubbs was a Poor-law medical officer for Upwell and Outwell, in the Wisbeach Union, and during this time he performed many important operations, and contributed various papers to branch meetings of the British Medical Association-among others, "On the Advantages of the Silver Suture," "A Case of Occluded Vagina, with successful operation," \&c.

Mr. Tubbs was buried at Upwell on the 17 th, amid every mark of respect and regret of many of his neighbours, upwards of a thousand of whom attended him to the grave. According to the local journal-"Thus passed away from amidst us one of the most useful men Upwell has ever possessed. 'He saved my life,' is the utterance of many; and with truth it may be said, that few men leave behind them such a host of living witnesses to testify to their skill."

\section{WIELIAKI T. COSTER, L.R.C.P. EDIN.}

Is the death of $\mathrm{Mr}$. Coster the profession has lost a talented, though perhaps little known, member. He received his medical education at University College, and, after holding some appointments connected with the hospital, he became surgeon to the St. Pancras Infirmary. He resided there some years, and then, inding the work very onerous, he obtained the surgeoncy to the Central
London District Schools, Hanwell, eight years ago, which appointment ha held up to the time of his death. He was a diligent wnilsor in his profession, and, whatever subject he took np, he was never satisfied until he had made himself master of it. In chemistrr he took great delight, and was a skilful mauivnlator. His name has been connected with a proparation for ringrorm, composed of oil of tar and iodine, and which is known by the name of "Coster's paint." He was one of those men who must always find employment of one sort or another, and he did not confine himself to purely protessional purstits : in photography he was unusvally successfnl; in music he was an accomplished periormer on the violincello; in natural history he took up the study of bees, and he had proposed to lave published some investigations he made on their babits and diseases, but, unfortunately, before he conld do so, he was carried off on the 12 tb inst., by an attack of hæmoptysis, at the early age of forty-one. During the last few years of his life his health had been delicate, and this, added to a retiring disposition, prevented his beino better known; but his own immediate friends recognised his great abilities, and much deplore his premature end.

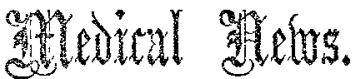

Royal College of Surgeons of England.-The following gentlemen, having passed the required examinations for the diploma, were duly admitted Members of the College at meetings of the Court of Examiners on the 17th and 18th inst. :-

Branfoot, Arthur M., Kennington-park-road.
Browa, Thomas L., L.R.C.P. Sdin., Bodvari, North Wales.

Buchanan, Waiter, L.S.A., Chatham.

Bunting, James, L.S.A., Tottenham.

Button, Horace G., L.S.A., Bermondsey.

Cooke, Edliston H., M.B. Aberd., Jamaica.

Coombe, George A., L.S.A., Burnham, Essex.

Crackle, Thomas A., L.S.A., Nottingham.

Crackle, Thomas A., L.S.A., Nottingham.

Lvans, Alfed H., L.S.A., Derby.

Grans, Alfred H., L.S.A., Derby.

Harric, Arthur G. R., L.R.C.P. Lond., Staines.

Hill, Thomas, L.S.A., Sonldern, Oxon.

Hind, Hemry, L.S.A., Stocktor-on-Tees.

Hugeins, Scmuel T, I.S.A., Banbury, Oxon.

Jollite, John, L.S.A., Shepherd's-bush.

Laces, Thomas W., L.S.A., Loughborough.

Mar, Thomas, L.S.A., Bicester.

May, Thomas, L.S.A., Bicester.

Palmer, Charles de Miontmorency, M.D. Dub., Dublin.

Palmer, Charles de Miontmorency, M.D. D

Parsons, Sidney, L.S.A., Wells, Somerset.

Perrigo, James, M.D. McGill Coll. Montreal, Montreal.

Rees, Howell, L.S.A., Maesteg, Sourh Wales.

Rodweil, Thomas H. B., Loddon, Norfolk.

Turner, Henry C., L.S.A., Lewes, Sussex.

Waller, Walter A. E., Bedford.

Wamer, Francis, L.S.A., Highbury-crescent.

White, Barrington S., L.S.A., Lavenham, Suffolk.

Wilder, Rev. Henry B., L.S.A., Sulham Rectory, Reading.

Nine other candidates were examined on the above-named

days, but failed to satisiy the Court, and were referred for a period of six months' further professional study.

At a meeting of the Court of Examiners on the $22 \mathrm{nd}$ inst. the following gentlemen passed the first part of the professional examination for the diploma of Fellow of the College :-

W. P. Goodall, William Rose, and Edward Nettleship, King's College J. A. Sharp, Wm. Williams, and J. D. Harres, Guy's Hospital; J. R. Birmingham; G. Chunder Roy, Calcutta; Henry Humphreys, UniverBity Collere; ;. Cooke, Paris: J. W. Ler, London Hospital.

Twelve other candidates were examined, but failed to satisfy the Court, and were referred back to their anatomical and physiological studies for a period of six months.

UNIVERSTY oF LoNDON. - The following is a list of the cancidates who have passed the recent second M.B. examination :-

First Ditistox.

Barnes, Edgar George, St. George's Hospital.

Bruce, John MIitchell, MI.A, Aberd., Lniversity of Aberdeen.

Burgess, Wm. Fredk. Richardson, Guy's Hospital.

Carter, Charles Henry, BA, University College.

Curnow, John, King's College.

De Liefde, John, Guy's Hospital.

Irvine, James Pearson, B.A., B.Se, Eniversity College.

Joubert, Charles Henry, St. Alar's's Hospital.

Pullurd, Freduriek, St.Thomas's Hospital.

Ruberts, Fichard Lawton, Cuiversity College.

Seaton, Edward Cox, St. Thomas's Hospital.

simith, Arthur William, Gur's Hospical

emitb, Richard Thomas, Cniversity College. 